$629.113(004)$

· . орний, . . олгов, . . удяну

ьвівський інститут ухопутних військ, ввів

озгляд ються різновиди стр тегій технічного обслуговув ння і ремонту з технічним ст ном $m$ н веден х р ктеристик іобл сть можлливого з стосув ння їхупр ктиці бройних ил кр їни.

лючові слов : експлу $m$ ційн н дійність, технічний $\mathrm{cm}$ н, технічне обслуговув ння, ремонт

ступ

ост новк проблеми. кту льним у технічній політиці бройних ил ( ) кр їни було і 3 лиш ється 3 вд ння щодо підтрим ння н норм тивному рівні пок зників експлу т ційної н дійності озброєння т військової техніки ( ), з одноч сним скороченням м тері льних, трудових т фін нсових витр т. ідомо, що головною передумовою з безпечення необхідного рівня експлу т ційної н дійності $€$ н уково обгрунтов н 3 відповідними критеріями p ціон льн форм орг ніз ції т викон ння їх технічного обслуговув ння і ремонту ( i ).

безпечення високих пок зників н дійності , модерніз ція т продовження термінів служби існуючого п рку , розвиток чинної їх системи i окреслені у «ерж вній прогр мі реформув ння т розвитку н 2006-2011 роки» т « ерж вній прогр мі розвитку озброєння і військової техніки н період до 2015 року».

н ліз ост нніх досліджень і публік цій. н укових публік ціях ост нніх років [1-4] вк зується н недоскон лість і недоліки чинної системи $\mathrm{i}$ т обгрунтовується потреб викон ння досліджень щодо вдоскон лення $і 1$ (розроблення нової) н основі визн ченого ді гностув нням ф ктичного технічного ст ну («3 ст НОМ»).

ет ст тті. цій ст тті викл дено основний зміст різновидів, х р ктеристик і сфери 3 стосув ння різних стр тегій і ст ном».

\section{сновний м тері л}

ідомі т кі стр тегії і $[1,5,6]$ :

- технічне обслуговув ння «з н пр цюв нням», для якого перелік, періодичність т обсяг опер цій визн ч ються зн ченням н пр цюв ння виробу з поч тку експлу т ції бо після к піт льного (середнього) ремонту;
- технічне обслуговув ння «з ст ном», 3 якого перелік, періодичність т обсяг викон ння опер цій визн ч ються ф ктичним технічним ст ном об'єкт н момент поч тку технічного обслуговув ння; - ремонт «з н пр цюв нням», під ч с якого обсяги розбир льних робіт т дефект ція скл дових об'єктів призн ч ються єдиними для їх п рку 3 лежно від н пр цюв ння $з$ поч тку експлу т ції бо після к піт льного (середнього) ремонту, перелік опер цій відновлення визн ч ється 3 ур хув нням результ тів дефект ції;

- ремонт «з технічним ст ном», під ч с якого перелік усіх опер цій визн ч ється 3 результ т ми ді гностув ння об'єктів н момент поч тку ремонту,

т кож $з$ д ними про пок зники експлу т ційної н дійності цих об'єктів.

основну озн ку, як визн ч $є$ стр тегію

i , беруть інформ цію про н дійність і технічний ст н . он використовується, крім цього, і при визн ченні періодичності т трудомісткості профіл ктичних робіт. озрізняють інформ цію: 3 ч сом отрим ння і використ ння пріорн т постеріорн ; 3 джерел ми отрим ння інформ ція про сукупності об'єктів і про окремий об'єкт. укупність цих видів інформ ції визн ч $є$ основу стр тегій і (т бл. 1).

тр тегії i відрізняються від стр тегій «з н пр цюв нням». они поляг ють не тільки в с мому х р ктері технологічних процесів i, ле й у розподілі м тері льних і трудових ресурсів.

тр тегія i «з ст ном» вим Г $є$ від конструкцій об'єктів високого рівня ремонтної технологічності, створення в дост тніх обсяг $\mathrm{x}$ ефективних з собів ді гностув ння т контролю, відповідного рівня розвитку виробничо-технічної б зи експлу т ційних і ремонтних підрозділів.

тр тегія $\mathrm{i}$ «з н пр цюв нням» вим г $є$ відповідного розвитку обслуговув ної б зи і з безпечення н цій основі обгрунтов них ресурсів для кожної сукупності однотипних об'єктів. 
тр тегіï і 3 різновид ми інформ ції про н дійність і технічний ст н об’єктів

\begin{tabular}{|c|c|c|c|}
\hline \multirow{2}{*}{ р ктер інформ ції } & \multicolumn{3}{|c|}{ нформ ція } \\
\hline & пріорн & & постеріорн \\
\hline ро сукупність об'єктів & «3 н пр цюв нням» & & $\begin{array}{c}\text { «3 ст ном» } 3 \text { контролем пок 3- } \\
\text { ників н дійності }\end{array}$ \\
\hline ро окремий об'єКТ & $\begin{array}{c}\text { «3 н пр цюв нням», яке вст нов - } \\
\text { люється для окремого об’єКт }\end{array}$ & & $\begin{array}{c}\text { ст ном» } 3 \text { контролем ді гностичних } \\
\text { п р метрів }\end{array}$ \\
\hline
\end{tabular}

ншими слов ми, стр тегія і «3 ст ном» спрямов Н н удоскон люв ння у м йбутньому конструкцій об’єктів, розвиток чинної виробничо технічної б зи, постійне викон ння поточних 3 вд нь 3 керув ння технічною експлу т цією. тр тегія і «3 н пр цюв нням» спрямов н перев жно н розвиток виробничої б зи і не сприяє досягненню необхідного рівня ремонтної технологічності конструкцій об'єктів [5]. сновними принцип ми стр тегій і «3 ст $\mathrm{HOM} \gg \mathrm{E}$ T $\mathrm{Ki}$ :

- принцип дотрим ння пл нової періодичності здійснення відповідного i . дн к пл нов ними є лише ч стин ст нд ртних регл мент них опер цій «3 н пр цюв нням» - роботи 3 технічного ді гностув ння і контролю об'єКтів і с м періодичність. емонтні роботи об'єктів вико нуються тільки 3 результ т ми ді гностув ння їх технічного ст ну;

- попередження відмов 3 умови досягнення м ксим льно можливого н пр цюв ння. опереджу в льний $\mathrm{x}$ р ктер тут 3 безпечується метод ми орг ніз ції постійного спостереження 3 об'єКТ ми під ч с експлу т ції 3 визн ченням ф ктичних зн чень пок зників їх н дійності, у ряді вип дків i 3 технічним ст ном сукупності т окремих об’єктів для своєч сного виявлення передвідмовно го ст ну ост нніх 3 н ступною своєч сною 3 міною ïх бо регулюв нням їхніх п р метрів;

- з безпечення економічності технічної експлу т ції методом оптиміз ції стр тегій $\mathrm{i}$. исок економічн ефективність досяг ється 3 р хунок н йповнішого використ ння пр цезд тності кожНого конкретного об'єКт

озр хунки i з рубіжн пр ктик пок зують [1], що 3 р хунок 3 пров дження стр тегії i техніки «3 ст ном» можн скоротити витр ти н технічну експлу т цію до $30 \%$.

лежно від ре льних можливостей визн чення гр ничного ст ну об'єктів т прийнятого критерію вст новлення термінів з міни зношених конструктивних елементів н об'єкті розрізняють відповідні стр тегії експлу т ції (використ ння): до вичерп ння ресурсу (терміну служби); до передвідмовного ст ну; до відмови. чевидно, що стр тегії і пов'яз ні зі стр тегіями експлу т ції (використ ння) об'єктів (т бл. 2). н веденого видно, шо для стр тегії експлу т ції виробів до вичерп ння ресурсу (терміну служби) рекомендов ною є стр тегія і «3 н пр цюв нням». ід ч с ремонту виробів можливі стр тегії «з н пр цюв нням» $\mathrm{i}$ «3 ст ном», що з лежить від виду об'єкт і рівня його контролю т ремонтоприд тності. кщо для нього прийнят стр тегія експлу т ції до передвідмовного ст ну, то необхідною й обов'язковою умовою іiі ре ліз ції н пр ктиці є прийняття стр тегії і відповідно «з ст ном» 3 контролем п р метрів і «3 ст ном» без контролю.

кщо ж, н вП КИ, об’єКТ обслуговується і ремонтується 3 контролем п р метрів, то рекомендов ною стр тегією експлу т ції (вико рист ння) його є стр тегія до перед-відмовного ст ну. ля об'єктів, які експлу туються 3 стр тегією до відмови, доцільними для i $€$ стр тегії відповідно «з ст ном» 3 контролем рівня пок зників н дійності, т «з н пр цюв нням» і«3 ст ном». тЖе, як пок зує н ліз, окремі зр зки можн експлу тув ти, обслуговув ти і ремонтув ти, як пр вило, тільки з однією із з зн чених стр тегій.

тр тегія «3 ст ном» 3 контролем рівня н дійності - одн 3 н йпоширеніших. он відповід є стр тегії експлу т ції (використ ння) об'єктів до відмови. е д є змогу істотно скоротити витр ти н технічну експлу т цію, і тому їі можн рекомендув ти до впров дження. о х $\mathrm{p}$ ктерних рис стр тегії 3 контролем рівня пок зників н дійності відносяться т кі: кожен 3 об'єктів експлу тується до відмови; міжремонтних ресурсів для них не вст новлюється. одо усіх однотипних об’єктів здійснюється контроль рівнів пок зників н дійності. р зі, якщо ф ктичний рівень н дійності того бо іншого типу об'єктів нижчий, ніж норм тивний, виконується ретельний н ліз причин відхилення i pe лізуються відповідні інженерно-технічні 3 ходи 3 метою його підвищення.

пров дження об'єктів 3 контролем рівня пок зників н дійності передб ч $є$ розв'яз ння низки орг ніз ційних т інженерно-технічних 3 вд Нь:

- орг ніз ція опер тивного збору й опр цюв ння 
з ємозв'язок між стр тегіями експлу т ції об'єктів т стр тегіями їх і

\begin{tabular}{|c|c|c|c|}
\hline \multirow{2}{*}{$\begin{array}{c}\text { тр тегії технічного обслуговув ння } \\
\text { i ремонту }\end{array}$} & \multicolumn{3}{|c|}{ тр тегії експлу т ції (використ ння) } \\
\hline & $\begin{array}{l}\text { до вичерп ння ресурсу } \\
\text { (терміну служби) }\end{array}$ & $\begin{array}{l}\text { до передвідмовного } \\
\text { ст ну }\end{array}$ & до відмови \\
\hline \multicolumn{4}{|c|}{ ехнічне обслуговув ння } \\
\hline «3 н пр цюв нНЯм» & + & - & - \\
\hline $\begin{array}{l}\text { «3 ст ном» } 3 \text { контролем ді гностичних } \\
\text { п р метрів }\end{array}$ & - & + & - \\
\hline «3 ст ном» 3 контролем пок зників н дійності & - & - & + \\
\hline \multicolumn{4}{|c|}{ емонт } \\
\hline «3 н пр цюв нням» & + & - & + \\
\hline «3 $\mathrm{cT}$ HOM» & + & + & + \\
\hline
\end{tabular}

інформ ції про пок зники н дійності, що уможливить вст новлення ф ктичних рівнів н дійності об'єктів;

- розроблення методики визн чення норм ти вних зн чень рівнів відповідних пок зників н дійності для кожного типу об'єктів;

- орг ніз ція опер тивного порівняння ф ктичного рівня пок зників н дійності 3 норм тивними $і$ прогнозув ння можливих н слідків;

- прийняття рішення про можливість продовження експлу т ції об'єктів і розроблення відповідних 3 ходів щодо з безпечення норм тивного рівня ї н дійності (призн чення дод ткових і ; змін періодичності контролю пок зників н дійності; змін умов бо режимів експлу т ції; викон ння конструкторських доопр цюв нь; перехід н стр тегію і «3 н пр цюв нням»).

жливою особливістю стр тегії

3

контролем рівня пок зників н дійності об'єктів є їі спрямов ність н регулярне оцінюв ння прид тності ix до под льшої безпечної $\mathrm{T}$ економічної експлу т ції. спішне з стосув ння цієї стр тегії можливе лише тоді, коли постійно контролюються експлу т ційні вл стивості т ких об'єктів т х р ктеристики їх н дійності:

- відмови яких не вплив ють н безпеку процесів, у яких вони використовуються;

- розподіл ймовірності безвідмовної роботи яких експоненці льний;

- н дійність яких з безпечує економічність їх використ ння;

- які м ють високу ремонтну т експлу т ційну технологічність:

- які м ють індик цію відмов з соб ми контролю [1].

онтроль рівня пок зників н дійност і об'єктів здійснюється, як відомо, п сивними експеримент льними із збору м сивів д них 3 под льшим опр цюв нням їх ст тистичними метод ми. им видом контролю охоплюється, як пр вило, більшість грег тів і вузлів, нез лежно від 3 стосовув них до них стр тегій і . дн к лише для стр тегії 3 контролем рівня н дійності цей вид контролю $€$ основним. цієї стр тегії, критерієм рівня технічного ст ну сукупності однотипних об'єктів (їх спр вності, пр цезд тності) $€$ рівень н дійності, який вир ж ється відпо відними пок зник ми. кі пок зники повинні нести м ксимум інформ ції про технічний ст н об'єктів, бути зручними для проведення опер тивного порівняльного н лізу з норм тивною 6 зою, т кож бути визн ч льними до змін процесу їх технічної експлу т ції (зміни умов і режимів експлу т ції, викон ння i ). чевидно, що т ким вимог м декв тно відповід тиме пок зник п р метр потоку відмов.

жливим для стр тегії 3 контролем рівня н дійності $€$ т кож вибір і призн чення норм тивного (гр нично допустимого) рівня н дійності, який вст новлений для кожного типу об'єктів з ур хув нням витр т н і і з лежить від обсягу вибірки контрольов них об'єктів.

ля поч ткового періоду впров дження стр тегії 3 контролем рівня н дійності вст новлення гр нично допустимих рівнів н дійності здійснюється н підст ві досвіду експлу т ції конкретних об'єктів бо їх н логів 3 попередні 2-3 роки. ри цьому вр ховується інформ ція про п р метричну н дійність об'єктів, яку н д ють 3 води-виготовлюв чі 3 результ т ми проведення стендових, ресурсних і з водських випробув нь. ля відстеження ф ктичних рівнів н дійності об'єктів і своєч сного виявлення відхилень зн чень пок зників від норм тивних рекомендується 3 стосовув ти щомісячний т щокв рт льний контроль, річний облік д них.

тр тегія i 3 контролем п р метрів включ є сукупність пр вил із визн чення режимів $\mathrm{i}$ регл менту ді гностув ння об'єктів і прийняття відповідних рішень про потребу їх обслуговув ння бо ремонту н основі інформ ції про ф ктичний технічний ст н. ля цієї стр тегії і експлу т ція об'єктів здійснюється до н ст ння передвідмовного ст ну. ля виявлення 
передвідмовного ст ну може 3 стосовув тись принцип призн чення 3 побіжних допусків $\mathrm{H}$ ді гностичні п р метри. ри цьому під допуском розуміють сукупність зн чень п р метрів, які зн ходяться між їх гр нично допустимим i передвідмовним рівнями. ихід п р метр 3 гр нично допустимий рівень озн ч $є$ відмову, досягнення передвідмовного рівня - потребу у викон нні профіл ктичних з ходів. держ ння поч ткової інформ ції про технічний ст н об'єкт здійснюється через вимірюв ння його функціон ль них і ді гностичних п р метрів.

івень 3 стосув ння технічного ді гностув ння визн ч $є$ глибину т якість визн чення технічного ст ну об'єктів, отже, пр вильність і е фективність прийняття відповідних рішень т с мої стр тегії. p диційний i н йпоширеніший підхід до визн чення технічного ст ну поляг $є$ в тому, що вибир ється деяк сукупність п р метрів, прово дяться вимірюв ння, результ ти яких порівнюють із 3 д ними меж ми обл сті пр цезд тності об'єКт . ри викон нні умов прин лежності п р метрів до 3 д ної обл сті прийм ється рішення про пр цезд тність об'єкт, в протилежному вип дку об'єкт визн ється непр цезд тним.

р ктерн рис розглянутої стр тегії і відсутність норм тивних міжремонтних н пр цюв нь об'єктів. ішення про продовження їх експлу т ції до н ступної перевірки бо потребу 3 міни (регулюв ння) прийм ється 3 результ т ми безперервного бо періодичного контролю ді гностичних п р метрів.

кономічн ефективність експлу т ції об'єктів досяг ється вибором оптим льної стр тегії і , як 3 безпечує екстрем льні зн чення цільової функції (мінімум питомої в ртості і , м ксимум коефіцієнт готовності техніки) при з д ному рівні ïх н дійності. стосув ння стр тегії i iз контролем п р метрів доцільно обмежити об'єкт ми, які з міркув нь безпеки не можуть бути допущені до експлу т ції, 3 економічних - до відпр цюв ння вст новленого міжремонт ного ресурсу чи терміну служби.

\section{Ис НОВ К И}

н ліз розглянутих стр тегій і «3 ст ном» пок з в їх поодиноку невисоку універс льність щодо стр тегій експлу т ції . метою впров дження цих стр тегій у пр ктику військ потрібне відповідне обгрунтув ння і комплексне поєдн ння їх, тобто створення нової зміш ної стр тегії. кту льність цього з свідчує нед вно викон н робот [7] н прикл ді інженерних військ.

\section{писок літер тури}

1. икович . боснов ние прогр мм технического обслужив ния и ремонт м шин / . . цкович. - .. н ние, 1983. - $78 c$.

2. удченко . . бгрунтув ння періодичності ді гностув ння елементів втомобілів, які не вплив ють н безпеку руху / . . удченко, . . етренко // бірник н укових пр ць . - 2006. - №.1. - . 10-13.

3. лмыков. . сновные н пр вления повышения н дежности и ремонтопригодности вооружения $u$ военной технике, ре лизуемые в стр н . . лмыков, . . олесник, . . $р$ мов // б.н ук. пр. б'єдн ного н уково-дослідного інституту бройних ил. - 2006. - ип.2(4). - .56-61.

4. евківський . . тр тегія розвитку вторемонтного виробництв в період глоб льних тр нсформ иій / . . евківський, . . озіс // пр вління проект ми, системний н ліз і логістик. 2002. - №2. - . 68-71.

5. мирнов . . бслужив ние и ремонт ви ционной техники по состоянию / . . мирнов, икович - . . p нспорт, 1987. - 272 c.

6. ехническ я эксплу $m$ ция ви ционного оборудов ния / [ од ред. . . оробьев ]. - .. p нспорт, 1990. - 296 c.

7. реденцер . . одель періодичного технічного обслуговув ння об'єктів озброєння $m$ військової техніки / . . реденцер, . . олох // б. н ук. пр.

. -2005 . - №2. - . 53-56.

дійщл до ред кцї̈ 15.11.2008

ецензент: доктор технічних н ук, професор . . узьо, ціон льний університет « ьвівськ політехнік », ьвів.

$$
\text { . . ерный, . . олгов, . . удяну }
$$

ссм трив ются р зновидности стр тегий технического обслужив ния и ремонт техники по техническому состоянию, приведен $x$ р ктеристик иобл сти возможного применения ихв пр ктике ооруженных ил кр ины. лючевые слов : эксплу $m$ иионн ян дежность, техническое состояние, техническое обслужив ние, ремонт.

\title{
STRATEGIES OF TECHNI CAL MAINTENANCE AND REPAIR OF ARMAMENT AND MILITARY MATERIEL «ON THE STATE»
}

\author{
N.V. Chornyi, R.V. Dolgov, R.G. Budeanu
}

The varieties of strategies of technical maintenance and repair of materiel on the technical state are examined, their description and possible application spheres in pr actice of Armed Forces of Ukraine are resulted.

Keywords: operating reliability, technical condition, technical maintenance, repairing.

(ㄷ . . орний, . . олгов, . . удяну 